\author{
Bondarenko Yu., \\ Bilyk 0., \\ Kochubei-Lytrynenko O., \\ Andronovich G.
}

\title{
STUDYING THE INFLUENCE OF GOLDEN FLAX SEEDS ON THE PROCESS OF FORMATION AND MATURATION OF WHEAT DOUGH
}

Model experiments were carried out to establish the effect of flax seeds on the processes that form and mature wheat-flour dough. The study objects were wheat flour of the highest grade (control) and a mixture of wheat flour of the highest grade and whole flax seeds in the amount of $15 \%$ by weight of flour (experimental sample), as well as dough made from them.

It was found during the research that the introduction of flax seeds to the dough system prolongs the duration of its formation by 22 minutes. In this regard, when making wheat bread with the addition of whole flax seeds, it is necessary to provide for an extended duration of kneading the dough. Along with this, the formation of the amount of gluten in the dough was observed that is less by $17 \%$ than that in the control, and which had a low unbound structure and less stretchability. The reason for this is that the slime-forming polysaccharides of flax seeds enter the liquid phase of the dough, thereby enveloping the protein substances, limiting their swelling, and, by sticking to the gluten frame, prevent the formation of a solid gluten structure. This further predetermines the formation of products of a smaller volume.

Studying the effect of flax seeds on dough maturation processes in terms of the amount of released carbon dioxide during fermentation has shown that in a sample with flax, the duration of dough fermentation can be reduced to 90 minutes.

The result of this study has also established that in the sample with the addition of whole seeds, due to the influence of water-soluble polysaccharides of flax, the accumulation and fermentation of sugars in the dough system occurs to a lesser extent than that in control.

The introduction of flax seeds leads to a decrease in the susceptibility of starch to gel formation. Consequently, it can be predicted that starch grains will not be able to bind enough water and, during baking, a less elastic crumb will be formed.

Keywords: gold flax seeds, gluten frame, dough fermentation, starch gel formation, flax seed polysaccharides.

Received date: 04.05.2020

Accepted date: 26.06 .2020

Published date: 31.10 .2020
Copyright (C) 2020, Bondarenko Yu., Bilyk O., Kochubei-Lytvynenko O., Andronovich G. This is an open access article under the CC BY license (http://creativecommons.org/licenses/by/4.0)

\section{Introduction}

A relevant direction for the development of a range of bakery products for healthy nutrition is the use of unconventional plant raw materials that possess adaptogenic properties [1]. Flax seeds may prove to be this type of raw material. Flax seeds are a valuable source of protein, fat, rich in unsaturated fatty acids, soluble and insoluble dietary fibers [2, 3], and lignans [4].

Flax proteins are of high biological value because they are balanced in terms of amino acid composition. According to the score by the All-Russian Research Institute of Flax Mechanization, the nutritional value of flax protein is 92 units [5]. Flax seeds are a source of unsaturated fatty acids with the predominant content of $\alpha$-linolenic (omega-3), which strengthens the walls of blood vessels, increasing their elasticity, which is effective in the treatment and prevention of atherosclerosis [6]. Flax seed lignans have a powerful antioxidant effect, which is why they are recommended in the prevention and treatment of atherosclerosis and coronary heart failure [7]. The hydro- carbon composition of flax seeds is mainly represented by soluble (slime-forming polysaccharides) and insoluble dietary fibers. In the human body, flax seed polysaccharides demonstrate radioprotective and immuno-protective properties, as well as contribute to lower blood cholesterol, diabetes prevention, reducing the risk of coronary failure [7, 8].

Let us consider the bakery market using Ukraine as an example. In the Ukrainian market, there are baked goods containing flax seeds, for example, Baltic bread with seeds, oatmeal bread with flax, bread with flax, toasted bread with flax, baguette with flax, etc. However, the content of flax in them is not large, which does not render these products functional properties.

At the National University of Food Technologies (Kyiv, Ukraine), experimental laboratory baking revealed that in order to enrich wheat bread with the physiological and functional ingredients of gold flax, its technologically possible dosage is $15 \%$ by weight of flour [9]. Further studies should establish the effect of flax seeds at this dosage on the processes of dough formation and maturation. 
This study object is wheat flour of the highest grade (control) and a mixture of wheat flour of the highest grade and whole flax seeds in the amount of $15 \%$ by weight of flour (experimental sample), as well as dough made from them.

The study aim is to establish the effect of flax seeds on the processes of dough formation and its maturation.

\section{Methods of research}

This study examined flax seeds produced by TOV Bioroztoropsha (Ukraine), a gold variety. To establish the effect of whole flax seeds on the processes of formation and maturation of dough made from wheat flour, we performed model experiments. Their implementation involved wheat flour of the highest grade (control) and a mixture of wheat flour of the highest grade and flax seeds in the amount of $15 \%$ by weight of flour (experimental sample).

The plastic-elastic characteristics of the dough were studied at the farinograph made by Brabender (Germany) [10].

The quantity and quality of gluten in the control and test samples were evaluated according to standard procedures [11].

The total amount of released carbon dioxide in semi-finished products was determined by a volumetric method at the device AG-1M [11].

To determine the amount of accumulated and fermented sugars in the dough, we prepared yeast and yeast-free straight dough (control) and with the addition of $15 \%$ of whole flax seeds by weight of the flour. The duration of dough fermentation was 120 minutes at a temperature of $30{ }^{\circ} \mathrm{C}$. The amount of sugars was determined by an iodometric method, which is based on quantifying the amount of oxidation copper before and after the reduction of the alkaline solution of copper by sugar [11].

To assess the susceptibility of dough semifinished products to the action of enzymes, we examined the temperature of gel formation and the time to achieve the highest viscosity at an amylograph made by Brabender (Germany) [10].

The results of the experimental study were statistically treated using the standard Microsoft Office software package.

\section{Research results and discussion}

The chemical composition of flax seeds is different from wheat flour, namely characterized by a high content of oil, protein substances, water-soluble dietary fibers.

In terms of the anatomical and morphological structure of flax seed, it is known that its shiny shell is a vitreous layer of dehydrated slime-forming polysaccharides. Since it is implied by the formulation of bread that flax seeds should be introduced in the whole form, it is this component during the dough preparation that would exert a significant impact on the processes of dough formation and maturation.

The polysaccharides of flax slime contain three highly molecular polysaccharides: $75 \%$ (of the total slime content) of the most viscous neutral polysaccharide with a molar mass of $1.2 \times 106 \mathrm{~g} / \mathrm{mol} ; 3.75 \%$ of the acidic polysaccharide AF1 with a molar mass of $6.5 \times 105 \mathrm{~g} / \mathrm{mol} ; 21.55 \%$ of the acidic polysaccharide AF2 with a molar mass of $1.7 \times 104 \mathrm{~g} / \mathrm{mol}$.

During dough kneading, the polysaccharides of a flax seed's shell, as a result of contact with water, enter a watersoluble state, forming viscous solutions, competing with proteins and starch of the flour for water.

The effect of whole flax seeds on the processes of dough formation was determined at a farinograph made by Brabender.

The farinograms of the control and test dough samples are shown in Fig. 1. The results from farinogram decoding are given in Table 1.
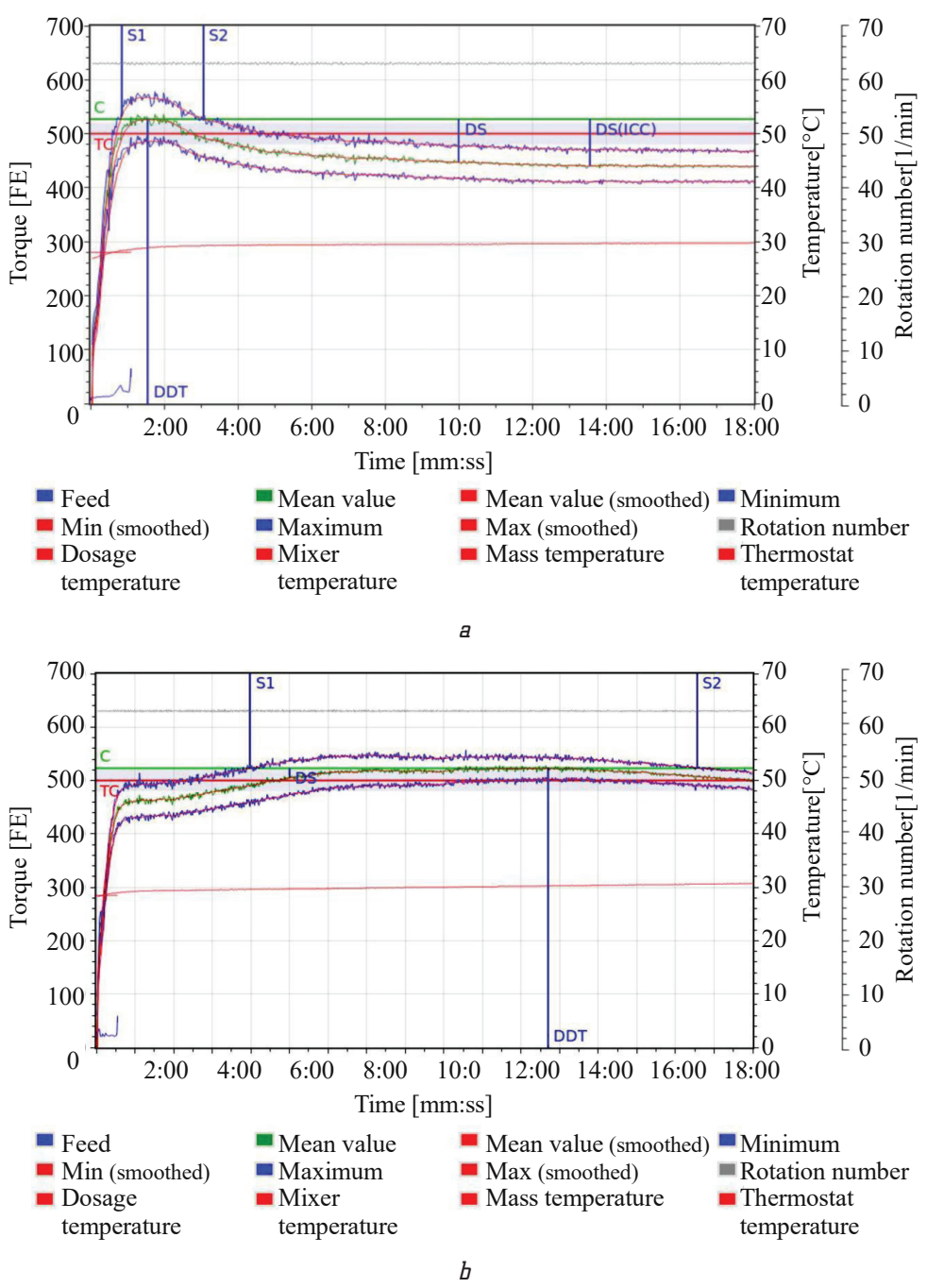

Fig. 1. Farinograms: $a$ - wheat flour of the highest grade (control); $b$ - a mixture of wheat flour of the highest grade and $15 \%$ whole flax seeds

Table 1

Structural and mechanical properties of dough according to a farinograph $(n=3, p \leq 0.95)$

\begin{tabular}{|l|c|c|}
\hline \multicolumn{1}{|c|}{ Indicator } & Control & $\begin{array}{c}\text { Whole flax seeds introduced, 15 \% } \\
\text { by weight of dough }\end{array}$ \\
\hline Consistency, device units & 527 & 523 \\
\hline Formation duration, min & 1.33 & 23.24 \\
\hline Elasticity, device units & 90 & 50 \\
\hline Stability, min. & 2.13 & 23.10 \\
\hline $\begin{array}{l}\text { Thinning after 12 min. } \\
\text { of kneading, device units }\end{array}$ & 87 & - \\
\hline
\end{tabular}


An analysis of the acquired data shows that the addition of whole flax seeds greatly prolongs the duration of dough formation. Thus, for the control sample, the duration of dough formation was $1 \mathrm{~min} 33 \mathrm{~s}$, while for the experimental sample, with the addition of $15 \%$ of flax seeds, $-23 \min 24$ s. In this case, the shape of curves in the farinograms of control and test samples also differs significantly. For the experimental sample, during the interaction of flax seed shells with water, the acidic fraction of the polysaccharide complex of the shell enters the liquid phase of the dough, which has a smaller molecular mass compared to the neutral fraction.

The transition of the acidic fraction of flax polysaccharides into the aqueous solution lasts up to 10 minutes, after which the more highly molecular polysaccharides begin to enter the hydrated state. The last to hydrate are the most highly molecular polysaccharides localized in the inner layers of the seed shell and in the endosperm. This pattern of the transition of flax polysaccharides was noted during the kneading of the experimental dough sample: over 8 min of kneading, the polysaccharides of acidic fraction were involved in the formation of dough, whose solutions did not significantly prevent the swelling of the protein substances of flour but slowed down this process. Subsequently, the liquid phase of the dough is entered by the polysaccharides of a neutral fraction, forming solutions of high viscosity with the dough system thickened, which significantly reduces and slows the swelling of flour proteins. This predetermines a significant extension of the duration of kneading of the dough. In this regard, when making bread with the addition of whole flax seeds, it is necessary to provide for an extended duration of kneading of the dough for the complete formation of the dough structure.

Our findings suggest that in the sample with flax seeds there is a decrease in the dough elasticity, compared to control. This is probably due to the deterioration of the development of dough gluten under the influence of slime-forming polysaccharides. Along with this, there is an extension of the duration of the resistance of the dough system, which, as a consequence of the properties of viscous solutions of water-soluble slime-forming polysaccharides, thickens and structures the system. Consequently, the test sample also does not demonstrate the thinning of the dough.

An important role in the formation of dough structural and mechanical properties belongs to gluten. Gluten in the dough is formed by the water-non-soluble proteins of wheat flour, gliadin and glutenin, which, when swelling, form a spongy-mesh structural basis. The study results are given in Table 2 .

Based on the study results (Table 2), it was found that the introduction of flax seeds causes a decrease in the amount of gluten, compared to the control, by $17 \%$.

The reason for the decrease in the amount of gluten may be the high water-absorbing ability of the non-starch polysaccharides of flax, which are competitors of protein for water; as a result of this, the gluten flour proteins are not swollen enough. However, one observes an increase in the hydration capacity of gluten. We assume this is due to the inclusion in the layers of gluten solutions of the non-starch polysaccharides in the form of viscous gels. In terms of physical appearance, in the case of adding flax seeds, gluten acquired a flaking unrelated structure. This is a confirmation that the slime-forming polysaccharides envelop protein substances, thereby limiting their swelling; by sticking into the gluten frame, they prevent the formation of a solid gluten structure. Slime also exerts an effect on the ruptured disulfide bonds in gluten proteins.

Table 2

Gluten quality indicators $(n=3, p \leq 0.95)$

\begin{tabular}{|l|c|c|}
\hline \multirow{2}{*}{\multicolumn{1}{|c|}{ Indicator }} & \multicolumn{2}{c|}{ Sample } \\
\cline { 2 - 3 } & Control & $\begin{array}{c}\text { Flax seeds introduced, } \\
15 \% \text { by weight of flour }\end{array}$ \\
\hline Amount of raw gluten, \% & 28.5 & 23.7 \\
\hline Moisture content, \% & 64.0 & 66.3 \\
\hline Hydration capacity, \% & 178 & 196 \\
\hline $\begin{array}{l}\text { Plasticity based on device, } \\
\text { device units }\end{array}$ & 55 & 57 \\
\hline Stretchability, cm & 14 (medium) & 12 (medium) \\
\hline Elasticity & Good & Good \\
\hline Color & Light, yellow shade & Greyish shade \\
\hline Structure characteristic & Good & Signs of loose structure \\
\hline
\end{tabular}

Disrupting the whole structure of gluten causes a decrease in the stretchability of gluten and a decrease in its elasticity.

One of the main processes that ensure dough maturing is fermentation, which is accompanied by the formation of carbon dioxide, alcohol, volatile organic acids, which enable dough loosening.

The fermentation process occurs both as a result of yeast life activities and as a result of the biochemical transformations of dough components.

The effect of flax seeds on the gas formation in dough was established based on the amount of carbon dioxide released during the fermentation of dough. At the same time, the conditions implied that the pieces of dough that were placed in the device contained the same amount of flour. That is, a variable factor that could affect the process is the amount of whole flax seeds added. The study results are shown in Fig. 2.

As the chart in Fig. 2 shows, gas formation in the dough with the introduction of both whole and crushed seeds for 120 minutes of fermentation occurs similarly to the control sample. Subsequently, the amount of carbon dioxide released in it increases slightly.

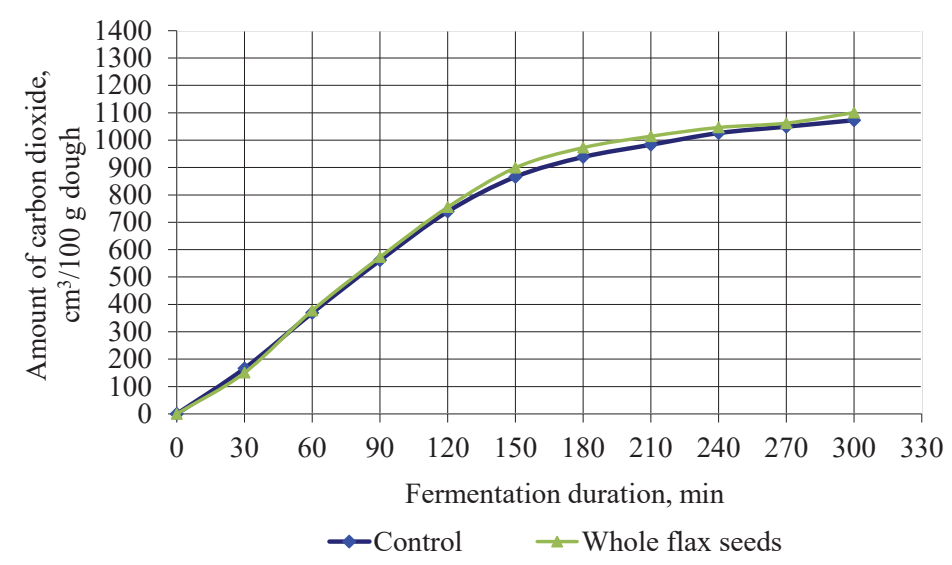

Fig. 2. Gas evolution in dough 
To understand the course of the fermentation process, it is necessary to analyze patterns in the dynamics of gas evolution. The curves of the dynamics of gas formation in the experimental samples are shown in Fig. 3.

The process of carbon dioxide release is staged. First, yeast ferments natural sugars of flour with the help of a zymase complex. After finishing, in the environment of natural sugars, they engage the maltase complex for the fermentation of maltose.

Fig. 3 demonstrates that in the control sample there is a two-step fermentation and the rebuilding of yeast for the fermentation of maltose occurs on minute 60 of fermentation. In the sample with the introduction of whole flax seeds, the character of the dynamics of carbon dioxide release has a similar two-stage character but the first peak is achieved 30 minutes later than in the control sample and the amount of carbon dioxide released is $40 \%$ higher than that in control.

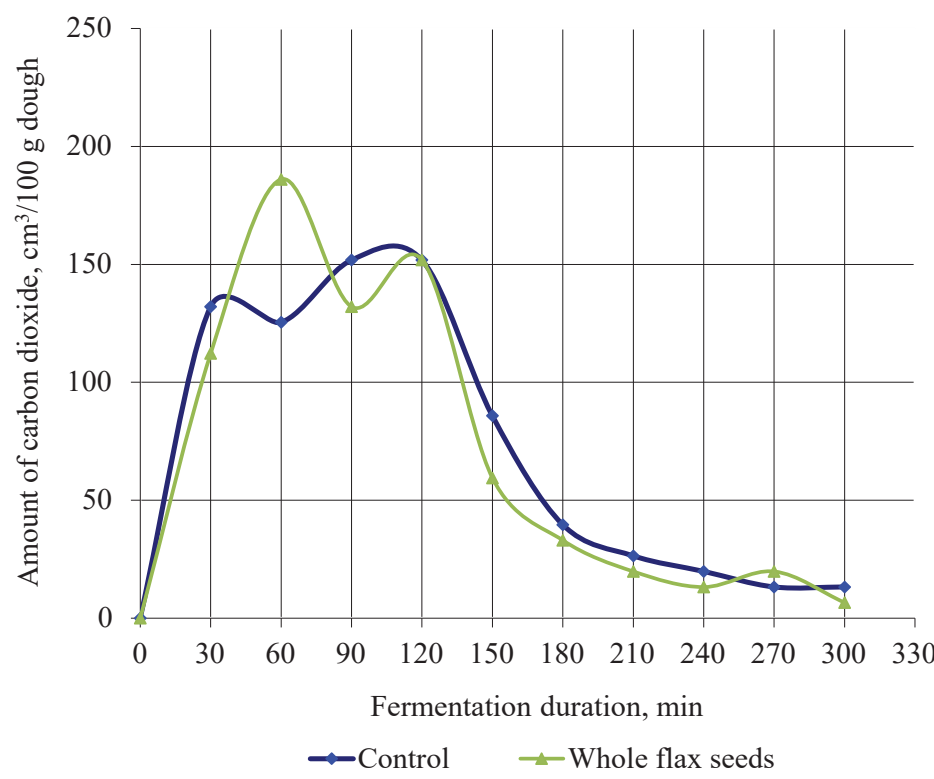

Fig. 3. The dynamics of carbon dioxide release in dough samples

We assume that this is due to the fact that during the extraction of slime-forming polysaccharides, the dough liquid phase is entered by other water-soluble substances of flax seeds. The process of transition of flax seed polysaccharides into the solution is accompanied by a parallel extraction of water-soluble fractions of proteins found in the shell of flax seeds, namely, the aqueous solution is first entered by the protein-polysaccharide associates representing an acid fraction, followed by direct polysaccharide structures with lower protein content. Water-soluble protein substances of flax in the dough liquid phase are additional nourishment for yeast. Because of this, the restructuring of yeast for the fermentation of maltose occurs 30 minutes later than that in control.

To achieve a good quality of products, the dough fermentation process must be stopped 30-40 minutes before reaching the peak of carbon dioxide release, so that the dough's aging stage coincides with the maximum gas formation. Based on this, we can assume that for a sample with whole flax seeds, the duration of fermentation would amount to 90 minutes.

Gas evolution in dough depends on the content of natural sugars in the flour but is more due to its sugar-forming capacity, which is ensured by the activity of amylase and the susceptibility of starch to amylolysis. The accumula- tion of sugars in dough during its maturation affects the intensity of fermentation processes and the formation of the color of the bread crust due to Mayer's reaction.

Along with the process of accumulation of maltose in dough, due to hydrolytic decomposition of starch, there is the fermentation of it by the microorganisms in the dough.

The correlation between the intensity of sugar accumulation in the dough due to the enzymatic hydrolysis of starch and the intensity of their fermentation by microorganisms affects sugar content in the dough before processing and baking.

The amount of sugars formed during dough maturation was determined by the difference between their content in the yeast-free dough after kneading and after 4 hours of its fermentation. The amount of fermented sugars - based on the difference between the amount of sugars in yeast dough after kneading and the amount of sugars formed in the yeast-free dough and the amount of sugars contained in yeast dough after 4 hours of fermentation.

It was established (Table 3) that the samples with the addition of whole flax seeds demonstrated less fermented and accumulated sugars. We assume this is due to the thickening of the liquid phase of dough by the polysaccharides of flax seeds, which, when unlimitedly swelling, form a viscous colloidal solution, which, by enveloping yeast cells, reduces their activity, and, by enveloping starch grains, reduces their adeptness to amylolysis.

To confirm this, a study was conducted at an amylograph. The process of gel formation of the dough system starch occurs during baking. For baking products, the mass of dough blanks of control and test samples is the same, the content of flour in them will be different. Since in the experimental sample part of the flour is replaced with flax seeds, due to the smaller content of flour in the dough blank, its starch content is smaller. To comply with the same conditions, when analyzing samples using the amylograph, we used $80 \mathrm{~g}$ of flour (control) and $80 \mathrm{~g}$ of the mixture of flour and whole flax seeds (flax seeds content is $15 \%$ by weight of flour).

Table 3

Accumulation and fermentation of sugars during dough fermentation, \% рег dry matter

\begin{tabular}{|l|c|c|}
\hline \multicolumn{1}{|c|}{ Indicator } & Control & $\begin{array}{c}\text { Flax seeds added, 15 \% } \\
\text { by weight of flour }\end{array}$ \\
\hline \multicolumn{3}{|c|}{ Yeast-free dough } \\
\hline Sugar content after kneading & 1.25 & 1.23 \\
\hline In 2 hours after fermentation & 2.03 & 2.22 \\
\hline Sugar formed & 0.78 & 0.48 \\
\hline & Yeast dough \\
\hline After kneading & 1.27 & 1.11 \\
\hline In 2 hours of fermentation & 0.79 & 0.67 \\
\hline Sugar fermented & 1.26 & 1.05 \\
\hline
\end{tabular}

It was established (Fig. 4, Table 4) that the addition of whole flax seeds does not affect the temperature and the time of the onset of starch gel formation but delays by 2 minutes the maximum time of suspension gel formation and increases by $2.5{ }^{\circ} \mathrm{C}$ the temperature of its 
maximum gel formation. At the same time, the viscosity of the suspension at the time of maximum gel formation in the sample with flax seeds is lower than in control and is $824 \mathrm{AU}$, while in control it is 1,000 AU.
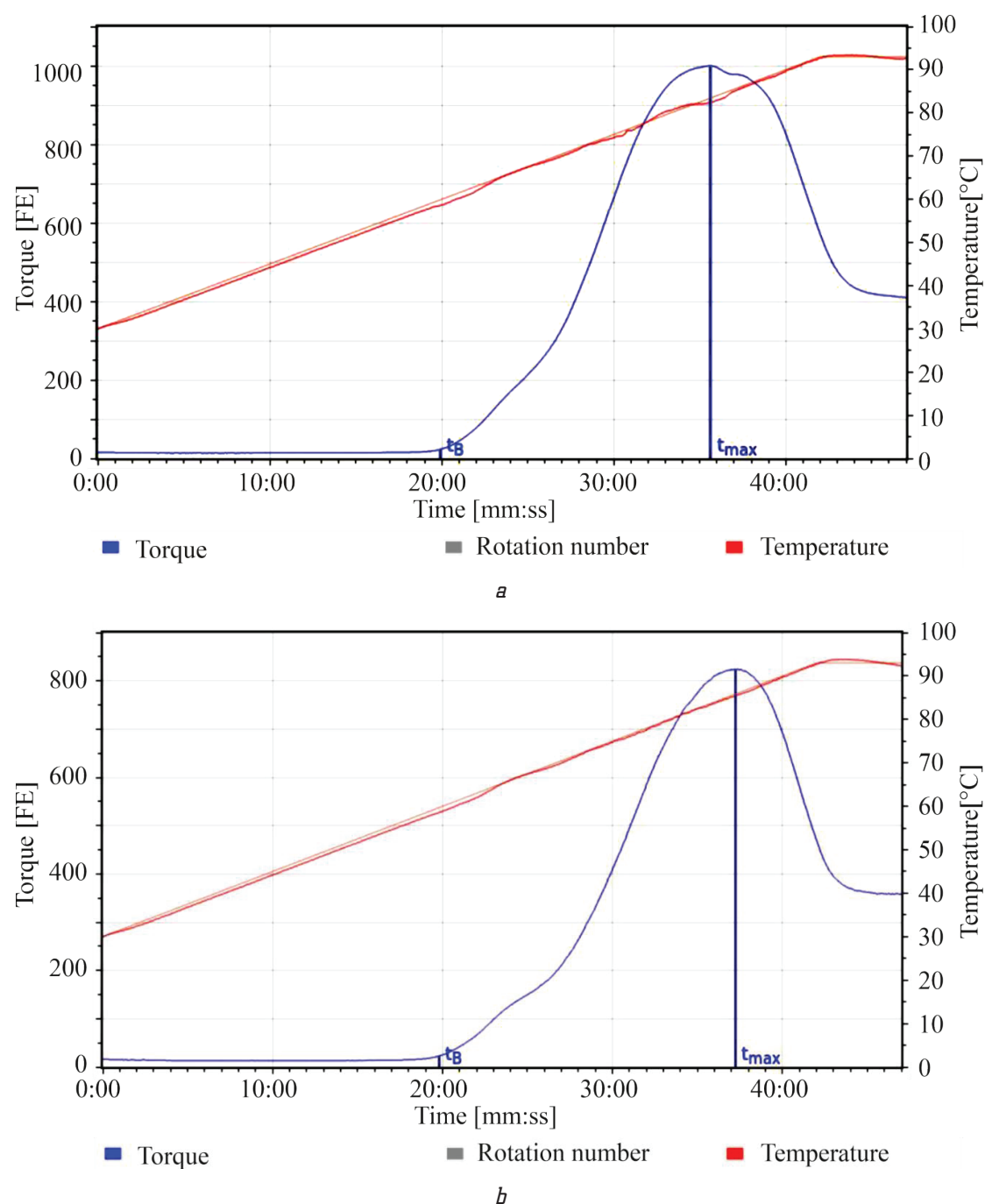

Fig. 4. Amilograms: $a$ - wheat flour of the highest grade (control) $b-$ a mixture of wheat flour of the highest grade and $15 \%$ whole flax seeds

Indicators of amilograms of the studied suspensions

\begin{tabular}{|l|c|c|}
\hline \multicolumn{1}{|c|}{ Water-flour suspensions } & Control & $\begin{array}{c}\text { Experimental sample with the addition } \\
\text { of } 15 \% \text { of whole flax seeds }\end{array}$ \\
\hline $\begin{array}{l}\text { The time when starch gel formation begins (the } \\
\text { formation of a viscous system), min }\end{array}$ & 19 & 19 \\
\hline $\begin{array}{l}\text { The time when the maximum gel formation of } \\
\text { starch occurs, min }\end{array}$ & 35 & 37 \\
\hline $\begin{array}{l}\text { Temperature of the onset of starch gel formation } \\
\text { (the formation of a viscous system), ' }\end{array}$ & 59.9 & 59.7 \\
\hline Maximum gel formation temperature, ' & 83.4 & 85.9 \\
\hline $\begin{array}{l}\text { Viscosity at the time of maximum gel forma- } \\
\text { tion, AU }\end{array}$ & 1,000 & 824 \\
\hline
\end{tabular}

This is due to the processes that will simultaneously take place in the system, namely the swelling of wheat flour starch and soluble dietary fibers of flax seeds. When flax seeds contact water, after a few seconds the watersoluble fractions of polysaccharides at the surface of the shell are hydrated with the formation of more viscous, compared to water, solutions. These water-soluble polysaccharides compete with starch for water; for its swelling, there remains less water than that in control. Thus, given that the mixture of flax seeds-flour will contain less starch than control, and this starch swells somewhat less, its gel formation occurs to a lesser extent compared to control, which predetermines the formation of a smaller viscosity of the system. In addition, enveloping starch grains with viscous solutions of polysaccharides, as well as the possible formation of complexes between starch and slime, will lead to a decrease in the susceptibility of starch to gel formation, which is the reason for prolonging the time of starch gel formation and an increase in the temperature of its gel formation. It can be predicted that due to the increased absorption of water by the components of flax, the formation of slime complexes with starch, starch grains during baking are not able to bind enough water; a less elastic crumb forms, which would stale faster during storage. Therefore, in the future, it is necessary to apply technological measures to improve the quality of the crumb for products with flax seeds and to prolong their freshness.

\section{Conclusions}

It was found during our study that the introduction of flax seeds prolongs the duration of dough formation by 22 minutes. Along with this, we noted the formation of the amount of gluten in the dough that is less by $17 \%$ than that in control; it had a loose unbound structure and less stretchability.

Studying the effect of flax seeds on the dough maturation processes in terms of the amount of released carbon dioxide has shown that in a sample with flax the restructuring of yeast on maltose fermentation occurs 30 minutes later than that in the control sample. This is due to the enrichment of the liquid phase of the dough with water-soluble substances extracted from the seed shell. At the same time, the duration of fermen- 
tation of the dough with flax seeds can be reduced to 90 minutes.

Based on the study results, it was also determined that in the sample with the addition of whole seeds, due to the influence of water-soluble polysaccharides of flax, there is a lesser extent of the accumulation and fermentation of sugars in the dough and the reduced susceptibility of starch to gel formation compared to control.

\section{References}

1. Vershinina, S. E., Kravchenko, O. Iu. (2010). Novye istochniki netraditsionnogo rastitelnogo syria $\mathrm{v}$ proizvodstve khleba. Khranenie i pererabotka selkhozsyria, 5, 51-52.

2. Enzifst, L. E., Bveo, M. E. (2014). Flaxseed (Linseed) fibre nutritional and culinary uses - a review. Food New Zealand, 26-28.

3. Ganorkar, P. M., Jain, R. K. (2013). Flaxseed - a nutritional punch. International Food Research Journal, 20 (2), 519-525.

4. Touré, A., Xueming, X. (2010). Flaxseed Lignans: Source, Biosynthesis, Metabolism, Antioxidant Activity, Bio-Active Components, and Health Benefits. Comprehensive Reviezes in Food Science and Food Safety, 9 (3), 261-269. doi: http://doi.org/10.1111/j.15414337.2009.00105.x

5. Sultaeva, N. L., Perminova, V. S. (2015). Issledovanie svoistv semian lna i razrabotka na ikh osnove tekhnologii khlebobulochnykh izdelii. Naukovedenie, 7 (1), 1-15.

6. Paschenko, L. P., Koval, L. A., Paschenko, V. L. (2006). Funktsionalnye svoistva semian maslichnogo lna. Uspekhi sovremennogo estestvoznaniia, 10, 98-99.

7. Shaltumaev, T. Sh., Mogilnii, M. P., Sigareva, M. A. (2015). Ispolzovanie produktov pererabotki semian lna dlia proizvodstva izdelii povyshennoi pischevoi tsennosti. Izvestiia vuzov. Pischevaia tekhnologiia, 5-6, 42-45.
8. Gutte, K. B., Sahoo, A. K., Ranveer, R. C. (2015). Bioactive Components of Flaxseed and its Health Benefits. International Journal of Pharmaceutical Sciences Review and Research, 31 (1), 42-51.

9. Andronovych, H., Bondarenko, Yu. (2018). Doslidzhennia vplyvu nasinnia lonu biloho na yakist pshenychnoho khliba. Naukovi zdobutky molodi - vyrishenniu problem kharchuvannia liudstva u XXI stolitti. Kyiv: NUKhT, 1, 166.

10. Lebedenko, T. Ie., Pshenyshniuk, H. F., Sokolova, N. Iu. (2014) Tekhnolohiia khlibopekarskoho vyrobnytstva. Praktykum. Odesa: Osvita Ukrainy, 392

11. Drobot, V. I. (Ed.) (2015). Tekhnokhimichnyi kontrol syrovyny ta khlibobulochnykh i makaronnykh vyrobiv. Kyiv: NUKhT, 902.

Bondarenko Yulia, PhD, Associate Professor, Department of Bakery and Confectionary Goods Technology, National University of Food Technologies, Kyiv, Ukraine, e-mail: bjuly@ukr.net, ORCID: http:// orcid.org/0000-0002-3781-5604

Bilyk Olena, PhD, Associate Professor, Department of Bakery and Confectionary Goods Technology, National University of Food Technologies, Kyiv, Ukraine, e-mail: bilyklena@gmail.com, ORCID: http:// orcid.org/0000-0003-3606-1254

Kochubei-Lytoynenko Oksana, PhD, Associate Professor, Department of Milk and Dairy Technology, National University of Food Technologies, Kyiv, Ukraine, e-mail: okolit@email.ua, ORCID: http:// orcid.org/0000-0003-0712-448X

Andronovich Galina, Postgraduate Student, Lecturer, Department of Food Technologies, Cherkasy State Technological University, Ukraine, e-mail: 1gryb1@ukr.net, ORCID: http://orcid.org/00000002-9522-4925 